\title{
Sports Development in West Java:
}

\author{
Sports policy review
}

\author{
Anang Setiawan ${ }^{1,2, *}$ \\ ${ }^{1}$ PJKR, ${ }^{2}$ Sekolah Pascasarjana \\ ${ }^{1}$ STKIP Nahdlatul Ulama Indramayu, ${ }^{2}$ Universitas \\ Pendidikan Indonesia \\ ${ }^{1}$ Kuningan-Indonesia, ${ }^{2}$ Bandung-Indonesia \\ *anangsetiawan@stkipnu.ac.id
}

\author{
Yudha M. Saputra, Amung Ma'mun \\ Faculty of sports and health education \\ Universitas Pendidikan Indonesia \\ Bandung, Indonesia
}

\author{
Nanang Fattah \\ Faculty of economic and business education \\ Universitas Pendidikan Indonesia \\ Bandung, Indonesia
}

\begin{abstract}
Sports development in Indonesia is currently a very interesting issue. Each region has shown quality in its sports through infrastructure development and sports achievements. Sports development in each region is outlined in the form of policies with the target of achievement and prestige of the region. Whereas the objectives of sports development cover various aspects, namely, making policies on sports, building sports infrastructure, and improving the quality of sports human resources (HR). The purpose of this paper was to find out sports development in terms of sports policy in West Java. Result: West Java sports development strategy is carried out with three major steps, forming the Sports and Youth Office (DISORDA), building sports infrastructure, and making Regional Regulation No. 1 of 2015 concerning Organizing Sports as a legal basis for sports development in West Java. Conclusion: Success in sports achievements made the province of West Java as one of the sports strength centers in Indonesia. In addition, West Java also received an award as the best organizer of the four-year sporting event. Whereas from an economic standpoint, the economy of the community increased after the implementation of the 2016 XIX National Games.
\end{abstract}

Keywords—sports development; sports policy; West Java

\section{INTRODUCTION}

At the beginning of the 21 st century, in some developed countries in sports achievements such as South Korea there has been a paradigm shift towards sports which initially as a prestige goal was later changed as a tool for broader goals for human life. The S4D (Sport for Development) program initiative aims to make a difference to the community as a whole including disadvantaged groups. This sports project (S4D) is used as a tool for positive social change, health and economy. Efforts have been made to make sports a sustainable social development tool in a society [1,2], contribute to job creation and employment [3], change gender roles and increase women's participation in exercise [4,5] and to increase awareness in the application of healthy lifestyles in disadvantaged communities [6-8].

Sports or physical activities carried out consistently will be closely related to quality of life, health, and well-being [9]. Conversely, if humans do not carry out physical activities according to their needs, they will most likely be susceptible to contracting diseases due to lack of motion (hypokinetic) and non-infectious diseases such as type 2 diabetes [10]. Low physical activity will increase the risk of obesity and many other chronic diseases including coronary heart disease, diabetes and colon cancer [11].

From developed countries to developing countries many health cases pose a real threat to their countries [12]. This problem solving can be done one of them by increasing physical activity or exercise as a preventive step [13,14].

As stated above that at present in some countries, the development of sports is not one of the final goals. Shifting the goal of sports development [15], becoming a development through sports is a global issue that is being widely debated $[16,17]$.

Sports development emphasizes sports as objects of development itself carried out by sports organizations. While sports for development make sports a tool for the purpose of building an area from various aspects such as social change and development [18,19], improving the economy of the community [20,21], creating jobs [22], and community empowerment [23,24]. The development program through sports will run well if in its implementation it synergizes with other government agencies [25], such as with the ministry of sports or service related to sports organizers in the region.

The United Nations through Sport for Development and Peace (SDP) program to achieve the Millennium Development Goals (MDGs) [26], recommends that: 
- Sports must be more integrated into development goals,

- Sports must include as a useful tool for development and peace,

- Sports-based initiatives must be included in country programs at the UN, if appropriate and in accordance with locally assessed needs,

- Programs that support sports for development and peace require greater attention and resources by governments and systems UN,

- Activities based on communication using sports must focus on targeted advocacy and social mobilization,

- The most effective way to implement the program is through partnerships.

The program has been widely applied by countries that have experienced social conflict. So that the sport is expected to play a role to minimize or even overcome various problems such as health and social.

\section{SPORTS DEVELOPMENT AND DEVELOPMENT THROUGH SPORTS}

Development of sports in a country is one of the important aspects in the national development process. One of the goals of sports development is to improve a better quality of life for the perpetrators, meaning that everyone can exercise according to their needs and abilities. In addition, sports development is also meaningful in an effort to improve the quality of mental, moral, spiritual health, character formation and character, leadership and struggle as competitive meanings.

The term sports development and development through sports seems to be a vague difference, even though both have very clear differences from the goal to the results they want to achieve. The first term, that sports development can be identified with the term traditional approach which emphasizes on improving the sport itself both achievements and completeness. Sports development refers to participation in exercise or physical activity which is a conceptual framework for sports development [15,27].

Related to this, in Indonesia, there are rules that have been compiled in the national sports system, namely Law No. 3 of 2005. It covers everything about sports, including rights, obligations, scope, coaching, sports development, and others. Related to the development of sports from the regional to the central level, it requires synergy from all parties, the community, local government (district / city, province), to the central government as stipulated in Chapter VII of Law No. 3 of 2005 concerning coaching and development of sports. Whereas in article 17 concerning the scope of sports explained that there are three types of sports that exist in Indonesia, namely sports education, recreational sports, and sports achievements.

Educational sports are held as part of the education process [18]. This means that sports in the world of education can also be used as a tool to educate students through the values contained in sports activities such as sportsmanship, respect, cooperation, the spirit of never giving up, and so forth. These values are expected to remain attached and applied in real life, so that positive social changes will affect their environment.

Recreational sports aim to obtain health, physical fitness and excitement; building social relations; and / or preserve and enhance the wealth of regional and national culture $[3,19]$. From this exposure it can be interpreted that in addition to the main goal of obtaining physical fitness, there are also other positive impacts of recreational sports, namely social impacts and enrichment or preservation of culture through various traditional sports. The social behavior of recreational sports players is expected to grow through social interactions that occur during sports activities. Thus, positive social changes that occur will affect the character development that will also support the development of the country as a whole. While cultivating traditional sports as local wisdom will show the true identity of the nation.

Performance sports are carried out through a planned, tiered, and sustainable development and development process with the support of sports science and technology which aims to increase the ability and potential of sportsmen in order to improve the nation's dignity [20]. At the regional level, achievement sports coaching is directed at efforts to prepare regional athletes for national event, namely the national games (PON). Whereas in the national level, the development and development of sports achievements by focusing athletes in the preparation of multi-event international sports such as the SEA Games, Asian Games, and Olympic Games.

Based on the law on the sports system, all matters concerning sports both at the national and regional levels are included, including sports development in three scopes, namely sports education, recreational sports, and sports achievements. If the development of sports in these three spheres can be realized optimally, then it does not rule out the possibility of a sports turn that is used as a tool for the development of the State through the values contained therein.

Below is one illustration of the sports development system. There are two perspectives from the picture of the sports development pyramid, (1) the influence from top to bottom the influence from the bottom up (2).

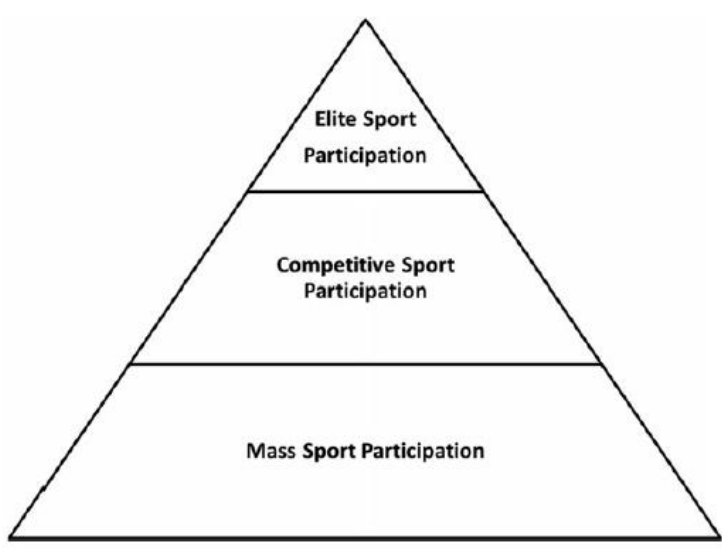

Fig. 1. Development of sports pyramid [17]. 
From these two perspectives, it has been proven by the State of South Korea using a top-down perspective to improve their sports performance at international sports [28].

The second term is development through sports, using sports as a development tool for a region, region or country from various aspects such as social and economic. Sports development can be used to improve the quality of life of individuals, community groups and the State [15]. By participating in sports, they understand that this will contribute to their health both physically and socially.

Development through sports or Sport for Development (SFD) is a program initiated by UN member states in 2000 which aims to solve social problems [17]. Another view of this second approach is to view sports as an engine to encourage development schemes [29], such as:

- Conflict resolution and intercultural understanding

- Building infrastructure, social, sports and society

- Increasing awareness, especially through education

- Empowerment

- Direct impact on physical and psychological health, as well as the general welfare

- economic development / poverty

One obvious example of the role of sport as a means of conflict resolution / problem solving is when South Korea and North Korea joined under one flag in some sports in the $18^{\text {th }}$ Asian Games 2018 Jakarta-Palembang.

\section{Sports DeVELOPMENT IN WeSt JAVA}

In 2010 West Java was designated as the host of Pekan Olahraga Nasional-PON- (National Games) XIX and Pekan Paralimpik Nasional-PEPARNAS- (National Paralympic Games) XV in 2016. It was used as a momentum for the improvement of sports facilities and infrastructure including the performance of West Java sports development marked by policy directions budget for the development of West Java sports development. The initial step taken at that time was to establish a separate service, namely the West Java Sports and Youth Office (DISORDA) through Regional Regulation No. 21 of 2008 concerning the organizational structure and regional apparatus. The West Java Province Sports and Youth Office was established on October 24, 2008 [30].

The presence of the Sports and Youth Office in West Java is expected to be able to integrate the development of Sports and Youth in West Java through several of its superior programs. One example of several programs that have been implemented by DISORDA West Java in organizing sports affairs is to prepare human resources in the form of sports personnel through a program Sarjana Pendamping Penggerak Pembangunan Olahraga (graduate program facilitating the development of sports) (SP3OR) with the activities of three programs, namely Minggu Bergerak (Gurak), Jumat Bersih dan Sehat (Jumsihat), dan Beladiri Budaya Masyarakat (BBM) pencak silat. This program is directed in order to increase the number of sports participation (angka partisipasi masyarakat berolahraga) (APMO) and is expected to be a means of socializing sports and community sports, both in order to maintain physical fitness and health which in turn will support high work productivity. In addition to these examples, there are several other programs related to fostering, developing, developing, or increasing sports in both sports, education and recreation.

In 2015, DISORDA received the basic legal power of sports through Regional Regulation No. 1 of 2015 concerning Sports Organization which was stipulated in the context of the need for regulation, development, development, implementation and supervision, as well as harmonization, synchronization and coordination of sports management in carrying out development in the field sports. This regional regulation is located as a guide in the implementation of sports by the Provincial Government and the community, and the preparation of sports policies in the District / City Region.

In this Regional Regulation, the general provisions, duties, authorities and responsibilities of the Provincial Government, the position, scope, planning, development and development of sports, sports, coaching and development of sports organizations, provision of infrastructure and facilities, sports industry, organization sports championships and festivals, standardization, sports accreditation and certification, sports science and technology development, community and business roles, coordination, cooperation, sports information system, awards, funding, administrative sanctions, criminal provisions, coaching, supervision and control, provisions cover.

The implementation of sports is functioned to develop physical, spiritual, social abilities, shape family health by paying attention to or carrying out physical activities, physical and / or sports training and form dignified national character and personality to be a strategic part in the effort to realize the Provincial Regional development vision and mission. The purpose of sporting activities is to support the achievement of national sports goals, enhance the sporting culture of the community which is reflected in the community who know, understand, understand, implement and enjoy the benefits of sports, preserve regional cultural heritage and traditions in the field of sports, and strengthen regional competitiveness in sports competitions national and international scope.

At the peak of the commemoration of the National Sports Day (Hari Olahraga Nasional) (HAORNAS) September 9, 2017 in Magelang, the government gave an award to West Java Governor Ahmad Heryawan as the 2017 sports coach (jabarprov.go.id). This can be used as an indicator that the West Java provincial government is very serious in its sports development.

\section{METHOD}

This article is a documentation study. Researchers examined various sources of documentation related to the development of sports in West Java. The aim is to describe the efforts and process of sports development carried out by the provincial government of West Java. 


\section{RESULTS AND DISCUSSION}

The results showed that West Java implemented a sports development strategy that began with forming a sports and youth office (DISORDA). Developing human resources in sports through the program Sarjana Pendamping Penggerak Pembangunan Olahraga (graduate program that supports sports development) (SP3OR) is one of the efforts undertaken by DISORDA in the process of sports development in West Java. Building sports infrastructure in the context of preparing to host the 2016 XIX National Games. Regional Regulation No. 1 of 2015 concerning Sports Organization is the legal basis for strengthening the process of sports development in West Java. Being a champion at National Games (PON XIX 2016) is one of the results of the development of sports in West Java.

\section{CONCLUSION}

Sports development is an inseparable part of the development of a region. Sports development in West Java focuses on three aspects, namely making policies about sports, building sports infrastructure, and improving the quality of sports human resources (HR). The three aspects of sports development were applied by starting to make a specific policy on sports, namely the Regional Regulation No. 1 of 2015 concerning the Implementation of Sports. It is intended that the sports sector has a legal umbrella that can be used as a basis for strength in sports development. After having a special sports policy, the next step is to build sports infrastructure which is a fundamental aspect of the continuity of sports. Especially for organizing the 2016 West Java PON XIX, the regency and city governments in West Java have built or renovated several venues to organize the multi-event national games. In addition, the government also prepares and improves its human resources to carry out tasks in the field of sports such as trainers, instructors, and other sports personnel.

\section{REFERENCES}

[1] B. Kidd, "A new social movement: Sport for development and peace," Sport in Society, vol.11, pp. 370-80, 2008

[2] J. Skinner, D.H. Zakus and J. Cowell, "Development through Sport: Building Social Capital in Disadvantaged Communities," Sport Manag Rev., vol. 11, no. 3, pp. 253-75, 2008.

[3] T. Kobayashi, M. Nicholson and R. Hoye, "Football "wantok": Sport and social capital in Vanuatu," Int Rev Sociol Sport, vol. 48, no. 1, pp. 38-53, 2013.

[4] M. Meier and M. Saavedra, "Esther Phiri and the Moutawakel effect in Zambia: An analysis of the use of female role models in sport-fordevelopment," Sport Soc., vol. 12, no. 9, pp. 1158-76, 2009.

[5] L.M.C. Hayhurst, "Corporatising sport, gender and development: Postcolonial IR feminisms, transnational private governance and global corporate social engagement," Third World Q, vol. 32, no. 3, pp. 53149, 2011.

[6] S. Caton, D. Chadwick, M. Chapman, S. Turnbull, D. Mitchell and J. Stansfield, "Healthy lifestyles for adults with intellectual disability: Knowledge, barriers, and facilitators*," J Intellect Dev Disabil., vol. 37, no. 3, pp. 248-59, 2012.

[7] R. Beech and M. Murray, "Social engagement and healthy ageing in disadvantaged communities," Qual Ageing Older Adults, vol. 14, no. 1, pp. 12-24, 2013.
[8] C.L. Cleland, M.A. Tully, F. Kee F and M.E, Cupples, "The effectiveness of physical activity interventions in socio-economically disadvantaged communities: A systematic review," Preventive Medicine, vol. 54, pp. 371-80, 2012

[9] T. Chen, E.C.M. Hui, W. Lang and L. Tao, "People, recreational facility and physical activity: New-type urbanization planning for the healthy communities in China," Habitat Int, vol. 58, pp. 12-22, 2016.

[10] M. Gram, R. Dahl and F. Dela, "Physical inactivity and muscle oxidative capacity in humans," Eur J Sport Sci., vol. 14, no. 4, pp. 37683, 2014.

[11] D. Ogilvie, K.E. Lamb, N.S. Ferguson and A. Ellaway "Recreational physical activity facilities within walking and cycling distance: Sociospatial patterning of access in Scotland," Heal Place, vol. 17, no. 5, pp. 1015-22, 2011.

[12] H. Kyröläinen, M. Santtila, B.C. Nindl and T. Vasankari, "Physica fitness profiles of young men: associations between physical fitness, obesity and health," Sports Med, vol. 40, no. 11, pp. 907-20, 2010.

[13] Professional Associations for Physical Activity, Physical Activity in the Prevention and Treatment of Disease. Swedish National Institute of Public Health, 2010.

[14] J. Kruk, "Physical activity in the prevention of the most frequent chronic diseases: An analysis of the recent evidence," Asian Pacific J Cancer Prev., vol. 8, no. 3, pp. 325-38, 2007.

[15] D. Shilbury, K.P. Sotiriadou and B.C. Green, "Sport development Systems, policies and pathways: An introduction to the special issue," Sport management review, vol. 11, no. 3, pp. 217-223, 2008.

[16] S.C. Darnell, "Power, Politics and "Sport for Development and Peace" Investigating the Utility of Sport for International Development," Sociol Sport J., vol. 27, no. 1, pp. 54-75, 2010.

[17] J.P. Ha, K. Lee and G. Ok, "From Development Of Sport to Development Through Sport: A Paradigm Shift for Sport Development in South Korea," Int J Hist Sport., vol. 32, no. 10, pp. 1-17, 2015.

[18] A. Lyras, P.J. Welty, "Integrating sport-for-development theory and praxis," Sport Manag Rev., vol. 14, no. 4, pp. 311-26, 2011.

[19] R. Spaaij, "The social impact of sport: Diversities, complexities and contexts," Sport Soc., vol. 12, no. 9, pp. 1109-17, 2009.

[20] R. Coleman and G. Ramchandani, "The hidden benefits of non-elite mass participation sports events: An economic perspective," Int J Sport Mark Spons, vol. 12, no. 1, pp. 24-36, 2011.

[21] Sport England, "Economic Value of Sport in England," Sport Engl. 2013.

[22] P.M. Downward and R. Ralston, "The Sports Development Potential of Sports Event Volunteering: Insights from the XVII Manchester Commonwealth Games," Eur Sport Manag Q, vol. 6, no. 4, pp. 333-51, 2006

[23] M. Tonts, "Competitive sport and social capital in rural Australia," J Rural Stud., vol. 21, no. 2, pp. 137-49, 2005.

[24] J. Partington and M. Totten, "Community sports projects and effective community empowerment: A case study in Rochdale," Manag Leis, vol. 17 , no. 1 , pp. 29-46, 2012

[25] N. Schulenkorf, J. Sugden and D. Burdsey, "Sport for development and peace as contested terrain: place, community, ownership," Int J Sport Policy, vol. 6, no. 3, pp. 371-87, 2014.

[26] United Nations, Sport for Development and Peace: Towards Achieving the Millennium Development Goals. United Nations Inter-Agency Task Force, 2003

[27] R. Bailey, D. Collins, P. Ford, A. MacNamara, M. Toms and G. Pearce, Participant development in sport: An academic review. UK: Sport Coach UK, 2010.

[28] J.W. Park, "Elite Sport Development in South Korea: An Analysis of Policy Change in the Sports of Athletics, Archery and Baseball, 2011.

[29] R. Levermore, "Sport: A new engine of development?" Prog Dev Stud., 2008.

[30] Dispora, "Sejarah" [online]. Retrieved from http://dispora.jabarprov.go.id/tentangdispora.aspx?tag=sejarah 